\title{
Husband's Perception on Anemia among Pregnant Women based on Cultural Perspective: A Qualitative Study
}

\author{
Darmawati Darmawati $^{1 *} \mathbb{D}$, Tongku Siregar ${ }^{2} \mathbb{D}$, Hajjul Kamil $^{3} \mathbb{D}$, Cut Husna $^{4}$ (D) Teuku Tahlil $^{5} \mathbb{D}$ \\ ${ }^{1}$ Department of Maternity Nursing, Faculty of Nursing, Universitas Syiah Kuala, Aceh, Indonesia; ${ }^{2}$ Laboratory of Reproduction, \\ Veterinary Faculty of Veterinary, Universitas Syiah Kuala, Aceh, Indonesia; ${ }^{3}$ Department of Management Nursing, Faculty of \\ Nursing, Universitas Syiah Kuala, Aceh, Indonesia; ${ }^{4}$ Department of Medical and Surgical Nursing, Faculty of Nursing, Universitas \\ Syiah Kuala, Aceh, Indonesia; ${ }^{5}$ Department of Community Nursing, Faculty of Nursing, Universitas Syiah Kuala, Aceh, Indonesia
}

Edited by: Mirko Spirosk Citation: Darmawati D, Siregar T, Kamil H, Husna C, Tahlil T. Husband's Perception on Anemia A Qualitative Study. Open Access Maced $J$ Med Sci. 2022 Jan 01; 10(G):6-13 https://doi.org/10.3889/oamjms.2022.7617 Keywords: Anemia; Culture; Husband; Pregnant women Correspondence: Darmawati Darmawati, Department of Maternity Nursing, Faculty of Nursing, Universitas Syia Kuala, Aceh, Indonesia E-mail:darmawati.fkep@unsyiah.ac.id Received: 16-Oct-202 Accepted: 11 -Dec-2021

Copyright: ๑ 2022 Darmawati Darmawati Tongku jbSiregar, Hajul Kamil, Cut Husna, Teuku Tahli Funding: This research did not receive any financial support Competing Interests: The authors have declared that no competing interests exis Open Access: This is an open-access article distributed under the terms of the Creative Commons AttributionNonCommercial 4.0 International License (CC BY-NC 4.0)

\begin{abstract}
BACKGROUND: Anemia is one of the most common nutritional problems during pregnancy. Husbands have an important role in supporting their wives in pregnancy to prevent complications. Husband's culture and beliefs will
\end{abstract} affect support for the health status of pregnant women.

AIM: This study aims to explore husbands' perceptions regarding anemia and cultural beliefs related to pregnancy.

METHODS: This qualitative study was conducted using twelve in-depth interviews (IDIs) with husbands who have pregnant wives who were recruited through a purposive sampling method. Data were collected through IDIs using open-ended questions to gain insight about Husband's Perception on Anemia among Pregnant Women based on Cultural Perspective. Data analysis was conducted by an inductive content analysis method to evaluate, encode, and analyze the interview's result.

RESULTS: Four themes emerged from interviews: (1) Husbands' happiness and support to their wives during pregnancy; (2) Husbands' perceptions and actions related to anemia symptoms; (3) Cultural beliefs during pregnancy believed by Acehnese people; and (4) the importance of local wisdom-based counseling.

CONCLUSIONS: Our findings provide new insights into how husbands' perceptions on anemia during pregnancy, how they support their pregnant wives, and what their believed in cultural views about pregnancy. These findings would assist in developing/adapting more strategic policies to prevent anemia in pregnancy.

\section{Introduction}

Anemiaduring pregnancyisanutritional problem and one of the leading causes of maternal mortality and morbidity worldwide [1]. Anemia in pregnancy is defined as a hemoglobin level $<11 \mathrm{~g} / \mathrm{dl}$ [2]. Globally, anemia in pregnancy is affecting 32.4 million pregnant women in the world [3]. Currently, the Indonesian prevalence of anemia in 2018 was $48.9 \%$; while in Aceh Besar district was $37.1 \%$ [4], [5]. According to World Health Organization, anemia could be a serious problem if the prevalence in a study population is $\geq 40 \%$, so urgent action is needed to overcome this problem [6].

Anemia can cause harm to the mother and the unborn baby, which can cause postpartum hemorrhage in terms of uterine atony [7], eclampsia, infection [8], can increase the risk of low birth weight and prematurity [9]. Among the many identified causes of anemia, iron deficiency is the commonest contributor cause. Accounted for approximately $50 \%$ of all cases of anemia in pregnancy are caused by this condition. Iron deficiency usually results from inadequate dietary iron intake [10]. Regularly taking iron supplements is one of the strategical implementations to meet the daily iron needs of the body. This action has been implemented by the Indonesian Government as a prevention and management program for anemia during pregnancy [11].

In fact, several previous studies found that there was a problem of non-compliance among pregnant women in consuming iron tablets [12], [13]. Study conducted by the Indonesian Ministry of Health also found that the level of compliance among

Indonesian pregnant women on consuming iron tablets in 2018 was $81.6 \%$ while in Aceh Province was $73.63 \%$. The target proposed by the Strategic Plan in 2018 was 95\% [4]. Apart from non-compliance factors, husband's support and quality of Antenatal Care (ANC) services, as well as cultural beliefs are also indirect causes of anemia [14], [15]. In Indonesia, one of the indicators that also affects this condition is the provision of communication, information, and education in ANC services provided, which so far only focuses on the overall health condition of pregnant women, not on a specific health problem experienced by them such as anemia [11]. As found in a previous study, counseling can change the behavior of pregnant women in consuming iron tablets [16]. 
In addition to the ANC provided, the role of family, especially husband, is essential in supporting pregnancy, especially during compliance in taking iron tablets. Previous studies found that families played an important role to support pregnant women's compliance in taking iron tablets, so exploring their perception especially for husbands is essential to support the prevalence reduction of anemia during pregnancy [15]. Husbands can be a good reminder for pregnant women to take iron tablets and provide nutritious food, so they must have good perception and understandings as well [7]. However, a person's ability to act is not only influenced by knowledge and understanding, but also by cultural beliefs. Local culture, which is believed to be true, could be a social control that can be used to take an action [17]. One of the communities who still adhere to the local culture is the Acehnese people, and Acehnese pregnant women also still get pregnancy information from cultural sources and religious beliefs [18].

On the other hand, Acehnese cultural beliefs regarding pregnancy also have several things that must be corrected and tend to conflict with the health aspect. As the results found in a study conducted by Darmawati et al. (2020), Acehnese pregnant women perceive that signs of anemia are common and they still believe in dietary restrictions [19]. Unfortunately, it can cause pregnant women difficulty to carry out their pregnancy well. For this reason, an exploratory study is needed to explore the perceptions of husbands as the closest person to pregnant women related to anemia and cultural beliefs in undergoing pregnancy. From the perceptions and cultural beliefs conveyed by the husbands, a common thread can be found on how this issue could be the cause of pregnant women's non-compliance in taking iron tablets which will be the cause of high prevalence in anemia during pregnancy. It is hoped that antenatal service providers can find out the problems faced by pregnant women from the perspective of their husbands and what they expect from the antenatal services they will receive.

\section{Methods}

\section{Study design and participants}

This study used a qualitative method with In-depth Interview (IDI) to explore the perceptions of husbands related to anemia and cultural beliefs in undergoing pregnancy. The data were collected in Aceh Besar District, Aceh Province, Indonesia. IDIs were conducted with twelve participants who lived in Aceh Besar District. The participant recruitment process was done using purposive sampling methods. The purpose was to recruit participants using inclusion criteria, which were a pregnant woman's husband, Acehnese, and voluntarily agreed to provide the required information. The participants were selected with the assistance of local midwife coordinators who made choices according to the criteria.

\section{Data collection and analysis}

All the IDIs were conducted by the first author. Participants' demographic data collected in this study were: Age, education level, current job, and their wives' gravida status. The semi-structured questions used in the interviews were reviewed by two external researchers. Participants were asked about their perceptions on pregnancy, the support given to their wives, preparations that have been made regarding pregnancy, their perceptions about anemia and iron tablet supplementation, their cultural beliefs and dietary restrictions, and their opinions about health services that are integrated with cultural beliefs.

A tape recorder and notebook were used to collect data during the interviews and take notes on the observed results, respectively. The IDI guide was written in Indonesian. The interview was lasted for 45-60 $\mathrm{min}$; the results were subsequently completely translated from Acehnese to Indonesian. However, the verbal interview results were evaluated, coded, and analyzed manually using the Inductive Content Analysis method [20].

Generally, all authors were involved in joint discussions to analyze the data found, developed codes, subcategories, categories, and themes, and the transcript results were read several times to obtain a good understanding of the context. Furthermore, the main themes and categories were developed based on study objectives that were capable of answering the study questions [21].

\section{Results}

In this study, we recruited 12 participants based on the consideration that data saturation had been achieved after conducting interviews with 12 participants and no new themes were found from the interviews conducted. A majority of the participants were 31-35 years old. Almost half of them had achieved a high level of education and work as entrepreneurs. Furthermore, the majority of their wives' gravida status was multiparous (Table 1).

Table 2 showed the meaning unit, code, category, subcategory, and theme of the study. The meaning unit explored the meaning of words or events both verbal and non-verbal that occurred during the IDI and then translated them into code. Data 
crosschecking were also assisted by three colleagues from the Faculty of Nursing Universitas Syiah Kuala, who experts in the qualitative study. The data transcript was carried out and analyzed manually to determine the meaning unit, code, sub-theme, and theme. Only the meaning unit, code, category, subcategory, and theme are then translated into English. Data analysis identified four themes among the perceptions of the husband about anemia during pregnancy and cultural beliefs: (1) Husbands' happiness and support to their wives during pregnancy; (2) husbands' perceptions and actions related to anemia symptoms; (3) cultural beliefs during pregnancy believed by Acehnese people; and (4) the of wisdom-based counseling (Table 2).

Table 1: Demographics of participants

\begin{tabular}{lll}
\hline Characteristics & $\mathrm{n}=12$ & $\%$ \\
\hline Age & & \\
$<30$ years old & 2 & 16.7 \\
$31-35$ years old & 6 & 50 \\
$36-40$ years old & 3 & 25 \\
$\quad>40$ years old & 1 & 8.3 \\
Education level & & \\
$\quad$ Low & 3 & 25 \\
Middle & 4 & 33.3 \\
$\quad$ High & 5 & 41.7 \\
Current job & 2 & 16.7 \\
Farmer & 3 & 25 \\
Civil servants & 3 & 41.6 \\
$\quad$ Entrepreneur & 5 & 16.7 \\
$\quad$ Workman & 2 & \\
Their wives' gravida status & & 33.3 \\
Primi & 4 & 50 \\
Multi & 6 & 16.7 \\
$\quad$ Grande & 2 & \\
\hline
\end{tabular}

\section{Husbands' happiness and support to their wives during pregnancy}

Husbands in this study revealed that they were very happy in welcoming their wives' pregnancy.
They were also grateful and felt the pregnancy was a blessing from Allah, as they said:

"My feelings at this time, Alhamdulillah, are very happy because this pregnancy is a pregnancy that we have been waiting for..." (P3)

"My feeling is obviously very happy. I had been waiting for this pregnancy for 1.5 years. Alhamdulillah. Sometimes, honestly, it is difficult to sleep at night but it is not too burdensome, because I feel happy" (P10)

Participants stated that they had not been any preparations made to support their pregnant wives so far. They said:

"There has been no preparation yet. Yes, until now, I do not have any preparation" (P1)

Unlike the other participants, some of them mentioned that there had been some preparations made to support their wives to reduce the symptoms felt by them, as they said:

"Preparations that have been made such as providing complementary foods and following doctor's advice such as providing vitamins, food

that good for fetal growth and obey what should be restricted" (P3)

"Alhamdulillah, there are some preparations. We routinely do checkups with the doctor." (P2)

\section{Husbands' perceptions and actions related to anemia symptoms}

Associated with the physical symptoms of anemia, such as nausea, vomiting, weakness, and pallor, participants had the perception that these

Table 2: Major findings with code, sub-categories, categories, and themes

\begin{tabular}{|c|c|c|c|c|}
\hline Meaning Unit & Code & Subcategory & Category & Theme \\
\hline $\begin{array}{l}\text { Give thanks to Allah because of their } \\
\text { wives' pregnancy }\end{array}$ & Feeling happy and thanks to Allah & Feeling in welcoming their wives' pregnancy & $\begin{array}{l}\text { The husbands' feelings } \\
\text { after knowing their wives } \\
\text { are pregnant }\end{array}$ & $\begin{array}{l}\text { Husbands' happiness } \\
\text { and support to their wives } \\
\text { during pregnancy }\end{array}$ \\
\hline $\begin{array}{l}\text { Husbands haven't done anything yet } \\
\text { Provide food, vitamins, and check } \\
\text { to doctor }\end{array}$ & $\begin{array}{l}\text { No preparations yet } \\
\text { Provide food, vitamins, and check to the } \\
\text { doctor }\end{array}$ & $\begin{array}{l}\text { Preparations made by the husbands in } \\
\text { supporting pregnancy }\end{array}$ & Husbands' support & \\
\hline $\begin{array}{l}\text { Lack of knowledge about anemia } \\
\text { symptoms and perceive that is normal } \\
\text { during pregnancy }\end{array}$ & Normal condition & Anemia sympoms & $\begin{array}{l}\text { Husbands' perception } \\
\text { about anemia symptoms } \\
\text { during pregnancy }\end{array}$ & $\begin{array}{l}\text { Husbands' perceptions } \\
\text { and actions related to } \\
\text { anemia symptoms }\end{array}$ \\
\hline $\begin{array}{l}\text { Weak and dizzy is abnornal during } \\
\text { pregnancy }\end{array}$ & Abnormal condition & & & \\
\hline $\begin{array}{l}\text { Do not know the iron tablet's benefit } \\
\text { and perceive that it is a medicine } \\
\text { Iron tablet is very good for pregnant } \\
\text { women }\end{array}$ & Husbands' knowledge about iron tablet & An understanding of iron tablets & $\begin{array}{l}\text { Knowledge and attitudes } \\
\text { about iron supplementation } \\
\text { as a preventive action of } \\
\text { anemia }\end{array}$ & \\
\hline $\begin{array}{l}\text { Remind their wives to take iron tablets } \\
\text { every eight o'clock at night } \\
\text { Did not remind their wives to take } \\
\text { iron tablets }\end{array}$ & Husbands' attitude about iron tablet & $\begin{array}{l}\text { Husbands' attitude in supporting their wives to } \\
\text { take iron tablets }\end{array}$ & & \\
\hline $\begin{array}{l}\text { No dietary restrictions during } \\
\text { pregnancy }\end{array}$ & There are no dietary restrictions & Good action in responding the cultural beliefs & $\begin{array}{l}\text { Cultural perceptions during } \\
\text { pregnancy regarding food }\end{array}$ & $\begin{array}{l}\text { Cultural beliefs during } \\
\text { pregnancy believed by }\end{array}$ \\
\hline $\begin{array}{l}\text { Their wives should not eat satay } \\
\text { because it is undercooked } \\
\text { Their wives should not consume } \\
\text { pineapple, fermented rice, and durian }\end{array}$ & $\begin{array}{l}\text { There are dietary restrictions such as } \\
\text { satay, pineapple, fermented rice, and } \\
\text { durian }\end{array}$ & There are dietary restrictions & & \\
\hline $\begin{array}{l}\text { Good parental advice should be } \\
\text { followed and bad ones should be } \\
\text { abandoned }\end{array}$ & $\begin{array}{l}\text { Good advice is taken and bad advice } \\
\text { should be eliminated }\end{array}$ & Good response in facing cultural beliefs & $\begin{array}{l}\text { Husbands' response } \\
\text { related to the cultural } \\
\text { beliefs' application in } \\
\text { pregnancy }\end{array}$ & $\begin{array}{l}\text { The importance of local } \\
\text { wisdom-based counseling }\end{array}$ \\
\hline $\begin{array}{l}\text { Strongly agree with culture-based } \\
\text { counseling }\end{array}$ & $\begin{array}{l}\text { The cultural approach counseling is very } \\
\text { good for Acehnese people }\end{array}$ & $\begin{array}{l}\text { Positive perspective regarding culture-based } \\
\text { counseling }\end{array}$ & $\begin{array}{l}\text { Husbands' view regarding } \\
\text { culture-based counseling }\end{array}$ & \\
\hline
\end{tabular}


symptoms were normal during pregnancy and there is no need to worry.

"Symptoms of weakness, dizziness, pallor are normal during pregnancy..." (P12)

"I don't understand. Actually, this is the first pregnancy of my wife (the participant answered with a little laughed).... Well, I think it is normal, it's always like that when a woman is pregnant, right?" (P5)

Meanwhile, several other participants said that anemia symptoms were abnormal for pregnant women, as they said:

"Dizziness and weakness are not normal because a pregnant woman should not be dizzy and weak (feel confident)" (P6)

Furthermore, this study also explored the perceptions and actions of husbands regarding their wives who are recommended to take iron tablets regularly to prevent anemia. There were some responses, some of them had a good understanding about iron tablets and some did not, as they said:

"I don't know and never saw that drug (iron tablets)" (P6)

"I'm afraid of the effect later. It could be that the drug can causes other bad condition in the body, so I do not allow my wife to take the drug (iron tablets)" (P11) too" (P5)

"Yes, it's not good, it can damage the kidneys,

"She (wife) has ever taken the tablet; the drug is a capsule which is used to increase hemoglobin level and there is also milk that good for pregnant women. I think the tablet is good, because it is useful for my wife's pregnancy and for the baby too, usually pregnant women are often feeling lack of blood (low hemoglobin level)" (P9)

For the participants who thought that iron tablet is beneficial, they stated that they supported their wives with many supportive actions, such as they usually remind their wives to take iron tablets at the best time and in accordance with the recommendations by the health workers in Public Health Centers, as they said:

"I am ready to remind her, I am very happy if I can accompany my wife. I always remind her at eight o'clock at night to take the iron tablet..." (P7)

"Yes, I am ready (to remind). I also ask for any recommendations from the health workers in Public Health Centers, if they say it's good to take it (iron tablet) daily, I will ready to remind my wife every day, I agree and will follow the health workers' recommendations" (P8)

Apart from positive support, there were also some participants who had a bad attitude in supporting their wives to take iron tablets, where they did not remind their wives to take the tablets. It can be seen from the words of the following participants:
"Yes... maybe not every night (reminds her to take the iron tablet), sometimes I think my wife will remember because of her awareness" (P12)

\section{Cultural beliefs during pregnancy believed by Acehnese people}

Husbands as participants in this study mentioned that they did not have any belief in food/activity restrictions for their wives related to their pregnancy and tended to follow the doctor's recommendations as they conveyed:

"There are no dietary or activity restrictions so far. Except for not consuming hard and sharp food. If it is normal food, then there are no restrictions" (P1)

"For me personally, I will ask the doctor first about what is recommended and what is not allowed. But the doctor said that actually pregnant women is allowed to consume every good food with sufficient portions" (P2)

In addition, there were several participants who stated that they highly upheld Acehnese cultural beliefs including dietary restrictions related to their wives' pregnancy, such as not eating satay, pineapple, fermented rice, and durian, as they conveyed:

"Yes, there are pineapple, tape (fermented rice or tubers), and durian. Once my wife asked for it, but I still did not allow her." (P8)

"Burned food (such as satay) must also be reduced because according to our parents' advices, burned foods are not cooked well and it will use charcoal or smoke when it is cooked, and that is not good for pregnant women" (P3)

\section{The importance of local wisdom-based counseling}

Participants in this study had a perception that cultural beliefs, which are advice from their parents, are things that must be followed if it brings goodness to them, and also can be abandoned if it brings harm or badness, as they said:

"Yes... If what is true and useful, we must follow, but if it is not true and brings danger, it must be adjusted, right? Yes, we can leave it (untrue values)" (P1)

Regarding the idea of an anemia counseling that is integrated with cultural beliefs or local wisdom, participants said that they strongly agreed and felt that it would have a good impact for pregnant women. It can be seen from their words:

"If we talk about Acehnese culture, it is already attached to our lives. If we do not implement the cultural beliefs in our daily life, then we will feel something that is blocked and it is forbidden. That is just a presupposition. Therefore, I think it is good if there is a treatment 
method that integrates with a cultural approach, so that Acehnese people can understand the delivered health messages better" (P7)

"If it is good for my wife and the unborn baby, then I will agree and support." (P4)

\section{Discussion}

Pregnant women are a group of women who are at high risk of anemia. It is due to an increase in the need for iron to meet the fetal development in the womb [22]. If this need is not fulfilled, a woman can experience anemia during pregnancy and breastfeeding [23]. To meet daily iron needs, pregnant women are also recommended to take iron tablets regularly. However, this recommendation is not accompanied by good adherence to its implementation [4]. Due to this vulnerability to nutritional problems, pregnant women really need to be supported by their closest people, so they can carry the pregnancy well, have their nutritional needs fulfilled, and increase their compliance in taking iron tablets.

Family is the closest group of people to pregnant women and has a strong influence on the way they live their pregnancies. The emotional support provided is also considered something that is essential and has an impact on the pregnancy process [24]. Regarding the support provided by the husbands, this current study found that pregnancy is something that husbands really look forward to and they are willing to help their pregnant wives, such as providing nutritious food to help fulfill the needed vitamins. It is also supported by a previous study conducted by Nur et al. (2019) who found that the husband supports his wife's pregnancy by accompanying her to the ANC service, reminding the wife to take iron tablets, and finding out information related to his wife's pregnancy [25]. These kinds of support are essential because a husband's participation in the wife's pregnancy is believed to be an important step to improve maternal health status [26].

Husbands and family play an important role in supporting pregnant women to have a good pregnancy. Husbands are individuals who have a significant role as determinants of pregnant women in their behavior which can also prevent anemia [27]. This current study revealed that Acehnese men as husbands and future fathers still lacked of knowledge regarding the conditions of anemia that can happen during pregnancy. Increasing the husband's knowledge is quite crucial considering that the husband is the biggest decisionmaker in the family. When the husband's role is not equipped with good knowledge, it will make the wife be late in getting health services [28]. In fact, the husband has a role in the family as a decision-maker and his actions can affect his wife's life [29]. In this study, the majority of participants had the latest education in the high category, so improving knowledge about pregnancy was not too difficult to do. Another study also found that husbands who have sufficient knowledge in detecting a risk in pregnancy have a positive contribution to reduce maternal mortality [30].

Indirectly, good knowledge accompanied by positive support given by husbands to pregnant women will increase compliance in consuming iron tablets. This current study found two situations where there were husbands that supported their wives to consume iron tablets regularly and there were also husbands who did not fully support. According to previous studies, pregnant women who receive support from their husbands, such as accompanying them during ANC visits, had a high level of adherence in taking iron tablet regularly [31], [32], [33]. The support that can provide is supporting their wives to consume iron tablets, reminding them to consume nutritious food and take iron tablets every day, finding out information that can support their wives' pregnancy, and accompanying them during ANC visits so the husbands can equip themselves with adequate information [7]. Families who play a good role will be able to improve the communication, interaction, and problem-solving faced by pregnant women as an effort to prevent anemia during pregnancy. The good intentions possessed by the husbands will indirectly affect their involvement in pregnancy [34].

In addition, cultural beliefs held by husbands will also affect the health status of pregnant women. It is because dietary restrictions that are believed culturally will have an impact on the nutrient inadequacies which are actually needed by pregnant women. This current study found that there were several dietary restrictions that husbands believe to their pregnant wives, including satay, pineapple, fermented rice, and durian. These beliefs and taboos were also observed in several cultures in other countries, such as in Ethiopia and India [35]. It is believed that food restrictions related to cultural beliefs that are violated will cause harm to the mother and the unborn baby [36], [37]. To overcome this problem, health workers have a big role to explain to the public, especially pregnant women and their husbands, to change their perceptions regarding the dietary restrictions they believe in. They can integrate cultural beliefs and traditional advices as contained in the hadis maja, so the health advice conveyed can be judged correctly by pregnant women, husbands, and their families. Hadis maja is a collection of advice that Acehnese people strongly believe after Al-Qur'an and the hadith of Prophet Muhammad SAW. The messages or cultural values contained in hadis maja are words from parents that can be used as advice, guidelines, and prohibitions, especially for a special condition such as pregnancy [38]. A qualitative study conducted by Darmawati et al. (2020a) found that Acehnese traditional leaders strongly encourage pregnant women to frequently read and apply the values contained in the 
hadis maja in their daily life. If implemented effectively, these advices can change the perceptions of pregnant women and their husbands, so pregnancy-related health problems such as anemia can be prevented [39].

ANC services that are integrated with cultural beliefs are believed will be useful to pregnant women by the husband. Therefore, the health information that is delivered to them does not conflict with cultural beliefs that have been traditionally believed for generations. According to a previous studies, providing information can increase knowledge and encourage behavior change of pregnant women [40]. Cultural beliefs that are believed by the husband cannot be ruled out, considering that the husband has an important role in making decisions in the family, so this belief will also influence the decision making [41]. The ANC services provided should be able to adapt these local beliefs and cultures that are believed and involve husbands in providing information related to the pregnancy. This practice will be able to increase the pregnant women and husbands in visiting ANC services regularly and they will feel safe and culturally beneficial [42]. Thus, the cultural views held by husbands and pregnant women should be integrated into ANC so the recommendations of health care providers can be applied into their daily life.

There are several limitations of this study. This study only explored the husband's perceptions without exploring other family members who could also influence family decisions regarding pregnancy. This study also did not consider whether the involvement of husbands in ANC services could affect pregnant women if they had better education and knowledge or when they had been given previous information regarding the danger signs of pregnancy.

\section{Conclusions}

This study provides important information about the perceptions of husbands as the closest person to pregnant women related to anemia and cultural beliefs in undergoing pregnancy. Four themes emerged from interviews: (1) Husbands' happiness and support to their wives during pregnancy; (2) husbands' perceptions and actions related to anemia symptoms; (3) cultural beliefs during pregnancy believed by Acehnese people; and (4) the importance of local wisdom-based counseling.

Other important information obtained includes the lack of husband's knowledge about pregnancy and anemia, especially regarding the importance of consuming iron tablets everyday as well as the culture of dietary restrictions that are believed by them can affect the daily nutritional intake of pregnant women. The results of this exploration can be used as an input in implementing generally accepted interventions for pregnant women, husbands, and their families based on aspects of local wisdom, cultural beliefs, and values that have been believed for a long time. Integrating local wisdom aspects in providing information through ANC services is a very good step to do considering that cultural beliefs are highly respected by husbands, so it can influence them in making decisions regarding their wives' pregnancies. It is hoped that this intervention can become a way for health workers to straighten the understanding and perceptions of husbands, to increase their knowledge, and to lead to good attitudes in supporting their pregnant wives.

\section{Acknowledgments}

We would like to acknowledge to the husbands who participated and shared their perceptions in this study. We also thank Aceh Besar District Health Office for granting permission and facilitated this study.

\section{Clinical Implications}

This study has a strong influence on the development of programs to reduce the incidence of iron deficiency anemia in pregnant women. The results of this study stressing for health workers in including husband's participation in ante natal care. Husbands are very influential people for pregnant women because they could provide a significant contributions and support as well as strong motivators.

\section{References}

1. Stephen G, Mgongo M, Hussein T, Katanga J, Stray-Pedersen B, Msuya SE. Anaemia in pregnancy: Prevalence, risk factors, and adverse perinatal outcomes in Northern Tanzania. Anemia. 2018;2018:1846280. https://doi.org/10.1155/2018/1846280 PMid:29854446

2. World Health Organization. Iron Deficiency Anaemia: Assessment, Prevention and Control. Geneva: World Health Organization; 2001.

3. Takele WW, Tariku A, Shiferaw FW, Demsie A, Alemu WG, Anlay DZ. Anemia among women attending antenatal care at the University of Gondar Comprehensive Specialized Referral Hospital, Northwest Ethiopia, 2017. Anemia. 2018;2018:7618959.

4. Indonesian Ministry of Health. Main Results of Basic Health Research 2018. Jakarta: Kementerian Kesehatan Republik Indonesia; 2018.

5. Aceh Besar District Public Health Office. Aceh Besar District Public Health Profile 2017. Aceh; 2017. 
6. World Health Organization. Worldwide Prevalence of Anaemia 1993-2005: WHO Global Database on Anaemia. Geneva: World Health Organization 2008.

7. Triharini M, Armini NK. Family functioning, intention, and adherence to iron supplementation among pregnant women in Surabaya, Indonesia. Eur J Biosci. 2020;14(2):6841-7.

8. Singh $\mathrm{P}$, Khan $\mathrm{S}$, Mittal R. Anemia during pregnancy in the women of Western Nepal. Bali Med J. 2013;2(1):14-6.

9. Di Renzo GC, Spano F, Giardina I, Brillo E, Clerici G, Roura LC. Iron deficiency anemia in pregnancy. Womens Health 2015;11(6):891-900.

10. Ayensu J, Annan R, Lutterodt H, Edusei A, Peng LS. Prevalence of anaemia and low intake of dietary nutrients in pregnant women living in rural and urban areas in the Ashanti region of Ghana. PLoS One. 2020;15(1):1-15. https://doi.org/10.1371/ journal.pone. 0226026

PMid:31978048

11. Indonesian Ministry of Health. Guidelines for Integrated Antenatal Care. Jakarta: Kementerian Kesehatan Republik Indonesia, Direktur Jenderal Bina Kesehatan Masyarakat; 2010. p. 1-40.

12. Abebaw B, Dessie Y, Baraki N, Oumer A, Gebru M. Adherence to iron and folic acid supplementation and associated factors among antenatal care attendants in Northwest Ethiopia. Int $\mathrm{J}$ Public Health Sci. 2020;9(1):20-8.

13. Sadore AA, Gebretsadik LA, Hussen MA. Compliance with ironfolate supplement and associated factors among antenatal care attendant mothers in Misha District, South Ethiopia: Community based cross-sectional study. J Environ Public Health. 2015;2015:781973. https://doi.org/10.1155/2015/781973 PMid:26839573

14. Chander S. Public Health Nutrition In Developing Countries. Part 1. New Delhi: Woodhead Publishing India Pvt. Ltd.; 2011.

15. Wiradnyani LA, Khusun $H$, Achadi EL, Ocviyanti D, Shankar AH. Role of family support and women's knowledge on pregnancy-related risks in adherence to maternal ironfolic acid supplementation in Indonesia. Public Health Nutr. 2016;19(15):2818-28. https://doi.org/10.1017/ S1368980016001002

PMid:27181394

16. Purbowati $\mathrm{N}$. Effect of counseling using flipchart and leaflet on the compliance of pregnant women in consuming iron tablet. Tunas Tunas Ris Kesehat. 2016;6(3):143-7.

17. Kasnodihardjo, Kristiana L. Cultural practice of pregnancy care in Gadingsari Village, Bantul, Yogyakarta. J Kesehat Reproduksi. 2013;3:113-23.

18. Iradukunda F. Food taboos during pregnancy. Health Care Women Int. 2020;41(2):159-68.

19. Darmawati D, Siregar TN, Kamil H, Tahlil T. Exploring Indonesian mothers' perspectives on anemia during pregnancy: A qualitative approach. Enferm Clin. 2020;2020:30551-9. https://doi.org/10.1016/j.enfcli.2020.11.002 PMid:33384251

20. Graneheim UH, Lundman B. Qualitative content analysis in nursing research: Concepts, procedures and measures to achieve trustworthiness. Nurse Educ Today. 2004;24(2):105-12. https://doi.org/10.1016/j.nedt.2003.10.001 PMid:14769454

21. Vaismoradi $M$, Jones $J$, Turunen $H$, Snelgrove $S$. Theme development in qualitative content analysis and thematic analysis. J Nurs Educ Pract. 2016;6(5):100-10.

22. Sanchez-GonzalezLR, Castro-Melendez SE,Angeles-TorresAC, Castro-Cortina N, Escobar-Valencia A, Quiroga-Garza A, et al. Efficacy and safety of adjuvant recombinant human erythropoietin and ferrous sulfate as treatment for iron defici.
Eur J Obstet Gynecol Reprod Biol. 2016;205:32-6. https://doi. org/10.1016/j.ejogrb.2016.08.004

PMid:27566219

23. Khalafallah AA, Dennis AE. Iron deficiency anaemia in pregnancy and postpartum: Pathophysiology and effect of oral versus intravenous iron therapy. J Pregnancy. 2012;2012:630519. https://doi.org/10.1155/2012/630519

PMid:22792466

24. Triharini M, Sulistyono A, Adriani M. Adherence to iron supplementation amongst pregnant mothers in Surabaya, Indonesia: Perceived benefits, barriers and family support. Int J Nurs Sci. 2018;5(3):243-8. https://doi.org/10.1016/j. ijnss.2018.07.002

PMid:31406832

25. Nur R, Mamar S, Demak IP, Fadhliah, Patui N, Radiah, et al. Husban behavior in pregnancy-postpartum care and wife's reproductive health. KnE Life Sci. 2019;2019:349-59.

26. Agushybana F. Influence of husband support on complication during pregnancy and childbirth in Indonesia. J Health Res. 2016;30(4):249-55.

27. Fernandes A, Sanga F, Gero S. The role of husband in assisting wife who suffer anemia in pregnancy. $\mathrm{J}$ Kesehat Masy. 2017;13(1):28-34.

28. Mizukoshi M, Ikeda M, Kamibeppu K. The experiences of husbands of primiparas with depressive or anxiety disorders during the perinatal period. Sex Reprod Healthc. 2016;8:42-8. https://doi.org/10.1016/j.srhc.2016.02.002 PMid:27179377

29. Alfatan PN, Darmawati D. Husband's support for pregnant women's compliance in consuming iron tablets. Nurs stud sci J. 2018;3(3):208-14.

30. Bin ZS, Das GR, Al Kibria GM, Hossain N, Bulbul MM, Hoque DM. Husband's involvement with mother's awareness and knowledge of newborn danger signs in facility-based childbirth settings: A cross-sectional study from rural Bangladesh. BMC Res Notes. 2018;11(1):286. https://doi. org/10.1186/s13104-018-3386-6 PMid:29743103

31. Aditianti, Permanasari Y, Julianti ED. Family and cadre supports increased iron pils compliance in anemic pregnant women. Penelit Gizi Makanan. 2015;38(1):71-8.

32. Alfatan PN, Darmawati D. Husband's support and pregnant women wife obedience in consuming iron supplements. J IIm Mhs Fak Keperawatan. 2018;3(3):208-2014.

33. Chourasia A, Pandey CM, Awasthi A. Factors influencing the consumption of iron and folic acid supplementations in high focus states of India. Clin Epidemiol Glob Health. 2017;5(4):180-4.

34. Lindberg LD, Kost K, Maddow-Zimet I. The role of men's childbearing intentions in father involvement. J Marriage Fam. 2017;79(1):44-59. https://doi.org/10.1111/jomf.12377 PMid:29977094

35. Chowdhury S, Chakraborty P. Food taboos in pregnancy and early lactation among women living in a rural area of West Bengal. J Fam Med Prim Care. 2017;6(2):169-70.

36. Gao H, Stiller CK, Scherbaum V, Biesalski HK, Wang Q, Hormann E, et al. Dietary intake and food habits of pregnant women residing in urban and rural areas of Deyang city, Sichuan Province, China. Nutrients. 2013;5(8):2933-54. https:// doi.org/10.3390/nu5082933 PMid:23912325

37. Mohammed SH, Taye H, Larijani B, Esmaillzadeh A. Food taboo among pregnant Ethiopian women: Magnitude, drivers, and association with anemia. Nutr J. 2019;18(1):1-9. https://doi. org/10.1186/s12937-019-0444-4

PMid:30904017 
38. Ismail B, Sufi R, Joesoef MD, Leumiek HK, Nurdin. Ensiklopedia Budaya Adat Aceh. Banda Aceh: Majelis Adat Aceh; 2018.

39. Darmawati D, Siregar TN, Kamil H, Tahlil T. Acehnese cultural leaders' perspective on anemia in pregnant women: A qualitative study. Adv Public Health. 2020;2020:8710254. https://doi. org/10.1155/2020/8710254

40. Navidian A, Rigi SN, Soltani P. Effects of group sexual counseling on the traditional perceptions and attitudes of Iranian pregnant women. Int J Womens Health. 2016;8:203-11. https:// doi.org/10.2147/IJWH.S104887

\section{PMid:27366105}

41. Lewis $S$, Lee A, Simkhada P. The role of husbands in maternal health and safe childbirth in rural Nepal: A qualitative study. BMC Pregnancy Childbirth. 2015;15(1):1-10.

42. Kaphle S, Hancock H, Newman LA. Childbirth traditions and cultural perceptions of safety in nepal: Critical spaces to ensure the survival of mothers and newborns in remote mountain villages. Midwifery. 2013;29(10):1173-81. https://doi. org/10.1016/j.midw.2013.06.002

PMid:23845450 